\title{
Assessing a Removable Mini-Lysimeter for Monitoring Crop Evapotranspiration Using a Well-Established Large Weighing Lysimeter: A Case Study for Barley and Potato
}

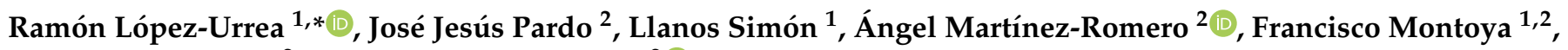 \\ José María Tarjuelo $^{2}$ and Alfonso Domínguez ${ }^{2}$ (D) \\ 1 Instituto Técnico Agronómico Provincial (ITAP) and FUNDESCAM, Parque Empresarial Campollano, \\ $2^{\mathrm{a}}$ Avenida-Nº 61, 02007 Albacete, Spain; 1sj.itap@dipualba.es (L.S.); fms.itap@dipualba.es (F.M.) \\ 2 Regional Centre of Water Research (CREA), Technical School of Agricultural and Forestry Engineering, \\ University of Castilla-La Mancha (UCLM), Campus Universitario s/n, 02071 Albacete, Spain; \\ josejesus.pardo@uclm.es (J.J.P.); angel.mromero@uclm.es (Á.M.-R.); jose.tarjuelo@uclma.es (J.M.T.); \\ alfonso.dominguez@uclm.es (A.D.) \\ * Correspondence: rlu.itap@dipualba.es
}

Citation: López-Urrea, R.; Pardo, J.J.; Simón, L.; Martínez-Romero, Á.; Montoya, F.; Tarjuelo, J.M.; Domínguez, A. Assessing a Removable Mini-Lysimeter for Monitoring Crop Evapotranspiration Using a Well-Established Large Weighing Lysimeter: A Case Study for Barley and Potato. Agronomy 2021, 11, 2067. https://doi.org/10.3390/ agronomy11102067

Academic Editor: Alejandro Galindo

Received: 3 September 2021

Accepted: 12 October 2021

Published: 15 October 2021

Publisher's Note: MDPI stays neutral with regard to jurisdictional claims in published maps and institutional affiliations.

Copyright: (c) 2021 by the authors. Licensee MDPI, Basel, Switzerland. This article is an open access article distributed under the terms and conditions of the Creative Commons Attribution (CC BY) license (https:// creativecommons.org/licenses/by/ $4.0 /)$.

\begin{abstract}
Further research is required on the measurement of crop evapotranspiration $\left(\mathrm{ET}_{\mathrm{c}}\right)$ to produce new or updated crop coefficients for a large number of crops using accurate weighing lysimeters. However, large weighing lysimeters are sometimes expensive and are not portable, and different prototypes of small-sized lysimeters may be a feasible alternative. This study evaluated the performance of a removable mini-lysimeter model to measure $\mathrm{ET}_{\mathrm{C}}$ and derive crop coefficients using a long-established large precision weighing lysimeter over a two-year period. The study was conducted during the 2017 and 2018 barley and potato growing seasons, respectively, at a lysimeter facility located in Albacete (southeast Spain). $\mathrm{ET}_{\mathrm{C}}$ values were determined using daily mass change in the lysimeters. Irrigation was managed to avoid any water stress. In the barley season, the minilysimeter underestimated the seasonal $\mathrm{ET}_{\mathrm{C}}$ by $2 \%$, the resulting errors in barley $\mathrm{ET}_{\mathrm{c}}$ estimation were an MBE of $-0.070 \mathrm{~mm} \mathrm{~d}^{-1}$ and an RMSE of $\pm 0.289 \mathrm{~mm} \mathrm{~d}^{-1}$. In the potato season, the mini-lysimeter overestimated the cumulative $\mathrm{ET}_{\mathrm{C}}$ by $5 \%$, the resulting errors in potato $\mathrm{ET}_{\mathrm{C}}$ measurement were an MBE of $0.222 \mathrm{~mm} \mathrm{~d}^{-1}$ and an RMSE of $\pm 0.497 \mathrm{~mm} \mathrm{~d}^{-1}$. The goodness of fit indicators showed a good agreement between the large and mini-lysimeter barley and potato $\mathrm{ET}_{\mathrm{C}}$ measurements at daily time step. Single $\left(\mathrm{K}_{\mathrm{c}}\right)$ and dual crop coefficients $\left(\mathrm{K}_{\mathrm{cb}}\right.$, crop transpiration $+\mathrm{K}_{\mathrm{e}}$, soil evaporation) were derived from the lysimeter measurements, the grass reference evapotranspiration $\left(\mathrm{ET}_{\mathrm{O}}\right)$ and the FAO56 dual $\mathrm{K}_{\mathrm{c}}$ approach; after temperate standard climate adjustment, mid-season values were $\mathrm{K}_{\mathrm{c} \text { mid (std) }}=1.05$ and $\mathrm{K}_{\mathrm{cb} \text { mid (std) }}=1.00$ for barley; and $\mathrm{K}_{\mathrm{c} \text { mid (std) }}=1.06$ and $\mathrm{K}_{\mathrm{cb} \text { mid (std) }}=1.02$ for potato. The good agreement found between $\mathrm{K}_{\mathrm{cb}}$ values and $\mathrm{f}_{\mathrm{c}}$ will allow barley and potato water requirements to be accurately estimated.
\end{abstract}

Keywords: lysimeter facility; mini-lysimeter performance; ET partitioning; single crop coefficient; dual crop coefficient; canopy cover; grass reference evapotranspiration; FAO56 approach

\section{Introduction}

There is a need to improve seasonal crop evapotranspiration $\left(\mathrm{ET}_{\mathrm{C}}\right)$ determinations and produce new or updated crop coefficients for a large number of species and cultivars of vegetables and field crops, fruit trees and vines under different environment conditions, irrigation systems and crop management (e.g., full and deficit irrigation). The aim is to compute the crop water requirements more accurately, resulting in an increase in irrigation water productivity and crop water use efficiency [1-3].

Many studies have used lysimeter evapotranspiration (ET) measurements for evaluation, calibration and validation of different ET approaches [4-8]. However, lysimeter 
measurements are very sensitive to environmental aspects, which are often not well interpreted or even taken into account. Moreover, there is a lack of necessary information on meteorological and environmental conditions, and processing of lysimeter data in published scientific papers, which calls into question the validity and representativeness of certain reported data sets [9].

When weighing lysimeters are well managed, they provide the most accurate ET data for short time steps with mass resolution ranging between 0.02 and $0.6 \mathrm{~mm}$, depending on the range of dynamic scale, the use of a counterbalance and resolution of load cells. These systems are undisturbed (monolithic) isolated blocks of soil or tanks filled with soil. They hang on a weighing mechanism in which crops are growing in the same vegetative and environmental conditions as the rest of the plot in which they were installed [4]. Mass changes in the lysimeter, i.e., water lost by evaporation, transpiration and drainage, and irrigation and rainfall inputs, are used for direct ET determinations.

An excellent review article by [9] reported the main factors affecting the accuracy of lysimeter measurements. For instance, one serious problem in lysimeter data is produced by a so-called "bloom effect" on small lysimeters, which means that the area of exposure of plant canopy is higher than the considered effective area of the lysimeter. In addition, these authors set out guidelines for the requirements of lysimeter-based ET measurements, including a minimum fetch of $50 \mathrm{~m}$ around the lysimeter, while plant population, crop height, leaf area, fraction of ground cover, irrigation water management and soil conditions inside the lysimeter must be identical to those in the rest of the field. Considering the typical environmental problems and limitations of lysimeters, Ref. [10] reported that lysimeter ET measurements can reasonably represent the ET values of the surrounding field.

Undoubtedly, a larger lysimeter surface area is desirable, as vegetation inside the area will be more representative of that in the outside field. However, the lysimeter area is restricted by economic and physical resources [11]. It can range between less than $1 \mathrm{~m}^{2}$ and more than $30 \mathrm{~m}^{2}$. The author in [12] reported that the cost of constructing and installing a repacked weighing lysimeter $(1.52 \mathrm{~m} \times 1.52 \mathrm{~m}$ square and $2.13-\mathrm{m}$ deep) was about 2500 USD, which could fluctuate depending on the available resources and equipment and labour costs. Therefore, large weighing lysimeters (LWL) are expensive and, unlike eddy covariance flux towers, cannot be moved from one field to another. The latter, however, have greater fetch requirements [9].

Some studies have reported the use of low-cost mini- or small-sized removable weighing lysimeters (mini-L) for different purposes. In this regard, Ref. [13] developed and tested a prototype of a low-cost weighing lysimeter for monitoring crop water requirements of potted plants. Later, based on this prototype of a lysimeter, Ref. [14] designed a small-sized weighing lysimeter for measuring water use of vegetable crops, which is easy to install, maintain and remove. The authors in [15] conducted a comparative study between a long-established LWL (2-m diameter and 2.5-m deep) and a mini-L (0.3-m diameter and 0.6-m deep) used to measure the components of the soil water balance (i.e., ET, rainfall and drainage). These authors reported a good agreement between ET measurements from each lysimeter.

Over the past two decades, a lysimeter facility located in Albacete (southeast Spain) has been used for testing different reference evapotranspiration $\left(\mathrm{ET}_{\mathrm{o}}\right)$ equations $[6,8,16]$; for measuring crop evapotranspiration $\left(\mathrm{ET}_{\mathrm{c}}\right.$ ) and producing (update) crop coefficients of field crops (e.g., sweet sorghum and canola) [1,17], vegetable crops such as broccoli [18] and vines (young and mature wine grapes) $[19,20]$. Moreover, it has been used for evaluating micrometeorological instruments, such as the eddy covariance flux system [21], remote sensing-based $\mathrm{ET}_{\mathrm{C}}$ approaches [22] and soil water balance models [23].

Recently, Refs. [2,3] have reported standard single $\left(\mathrm{K}_{\mathrm{c}}\right)$ and basal $\left(\mathrm{K}_{\mathrm{cb}}\right)$ crop coefficients for field and vegetable crops, which is an update of the FAO56 publication [24]. These authors highlighted the need for accurate $\mathrm{ET}_{\mathrm{C}}$ determinations to derive new (updated) crop coefficients as provided by lysimeter measurements. With the aim of transferability, observed mid- and end season single $\left(\mathrm{K}_{\mathrm{c} \text { mid }}\right.$ and $\left.\mathrm{K}_{\mathrm{c} \text { end }}\right)$ and basal $\left(\mathrm{K}_{\mathrm{cb} \text { mid }}\right.$ and $\left.\mathrm{K}_{\mathrm{cb} \text { end }}\right)$ crop coefficients should be adjusted to the standard climate (i.e., minimum relative humidity 
$\left(\mathrm{RH}_{\min }\right)$ of $45 \%$ and wind speed $\left(\mathrm{u}_{2}\right)$ of $\left.2 \mathrm{~m} \mathrm{~s}^{-1}\right)$. Based on the research studies conducted over the last 20 years, standard $K_{c}$ and $K_{c b}$ values have been updated, as well as ancillary crop parameters such as maximum values of root depth $\left(\mathrm{Z}_{\mathrm{r} \text { max }}\right)$, leaf area index $\left(\mathrm{LAI}_{\max }\right)$ and canopy cover $\left(\mathrm{f}_{\mathrm{c} \text { max }}\right)$.

However, the most common disadvantages and environmental problems of lysimeter systems can be aggravated by using mini- or small-sized lysimeters. A two-year study was conducted in our lysimeter facility, with the aims of: (a) assessing the performance of a removable mini-lysimeter for measuring crop ET using a long-established large precision weighing lysimeter and two data sets from each lysimeter, i.e., one growing season of barley and another of potato; $(b)$ determining standard single $\left(\mathrm{K}_{\mathrm{c}}\right)$ and basal $\left(\mathrm{K}_{\mathrm{cb}}\right)$ crop coefficients for barley and potato crops; (c) obtaining the relationship between the basal crop coefficient $\left(\mathrm{K}_{\mathrm{cb}}\right)$ and the fraction of ground cover $\left(\mathrm{f}_{\mathrm{c}}\right)$.

\section{Materials and Methods}

\subsection{Study Site Description and Lysimeter Data Processing}

This study is based on trials conducted during the 2017 and 2018 growing seasons of barley and potato, respectively, at the ITAP (Technical Institute of Agronomy) lysimeter facility in Albacete (southeast Spain) $\left(39^{\circ} 03^{\prime} \mathrm{N}, 2^{\circ} 05^{\prime} \mathrm{W}\right.$, elevation $\left.695 \mathrm{~m}\right)$. The soil is classified as Petrocalcic Calcixerepts [25]. Average soil depth inside the lysimeter and the surrounding field is about $40 \mathrm{~cm}$. At the beginning of the experiment, soil samples were taken at different depths to determine physical and chemical soil properties. Soil texture at this site is silty-clay-loam, with a basic $\mathrm{pH}$ that remains uniform through the soil profile. A more detailed description of soil properties in the lysimeter field can be found in [23]. Our lysimeter facility is located in a semi-arid environment, with a temperate Mediterranean climate with predominant dry and hot summers. The mean annual precipitation over the last 30 years is $314 \mathrm{~mm}$, which is mostly concentrated in the months of April and May and from September through November. Average mean, maximum and minimum temperatures are $13.8,24.6$ and $4.8^{\circ} \mathrm{C}$, respectively. Climatic data were gathered for a 30-year period (1987-2016) from a standard agrometeorological station located at the study site.

The lysimeters' (mini- and large) surface area and surrounding field were sown with barley (Hordeum vulgare L. cv. 'Shakira') on 7 February and were harvested on 5 July in 2017. Barley seeds were sown in rows 15-cm apart with a seed population of 400 seeds $\mathrm{m}^{-2}$. In the 2018 growing season, the lysimeter field (in and outside) was planted with potato (Solanum tuberosum L. cv. 'Agria') on 9 April and was harvested on 2 September. Potato plant spacing was $0.25 \mathrm{~m}$ within row and $0.75 \mathrm{~m}$ inter-row, resulting in 5.33 plants $\mathrm{m}^{-2}$. In the 2017 and 2018 seasons, the plant population inside the lysimeters and the surrounding field was similar (Figure 1), yielding $\mathrm{ET}_{\mathrm{C}}$ measurements that were sufficiently representative. In both seasons, fertilizer was applied according to the recommendations of the agrochemical analysis laboratory belonging to ITAP with the purpose of obtaining potential yields. In addition, the study site was managed following the cultural practices typically conducted in the area, aiming to avoid pests and disease effects on crop performance. The entire lysimeter plot is equipped with a solid set sprinkler irrigation system, with sprinklers placed on a grid of $15 \mathrm{~m} \times 12.5 \mathrm{~m}$ that supply a precipitation rate of about $8.6 \mathrm{~mm} \mathrm{~h}^{-1}$. Irrigation water management in the lysimeter plot followed the standard practice in the area for obtaining maximum yields, i.e., avoiding any water stress effects. Irrigation was applied every 2 to 17 days for barley crop in 2017 and every 2 to 20 days for potato crop in 2018, to replace $\mathrm{ET}_{\mathrm{C}}$ under pristine and no water stress cropping conditions, based on the lysimeter measurements and precipitation amounts measured. The barley and potato crops received 28 and 30 irrigation events throughout the 2017 and 2018 seasons, respectively. Soil inside both lysimeters was similar to the surrounding field soil with a limited rooting depth, and thus irrigation was managed for only crops root depth (i.e., $30 \mathrm{~cm}$ for barley and $40 \mathrm{~cm}$ for potato). In the root zone, the water holding capacity was $100.5 \mathrm{~mm}$ for barley and $132 \mathrm{~mm}$ for potato, and permanent wilting point was $61.5 \mathrm{~mm}$ for barley and $82 \mathrm{~mm}$ for potato, resulting in total available water of 39 and $52 \mathrm{~mm}$ for barley and potato, respectively. Irrigation was managed in both lysimeters to maintain non-limiting soil water content; thus, irrigation was applied to replace $\mathrm{ET}_{\mathrm{C}}$ when the lysimeter weight indicated 
that the soil water depletions ranged between $8 \mathrm{~mm}$ (in the early initial stage) and $16 \mathrm{~mm}$, for both experimental years. Therefore, this irrigation water management strategy ensured that a maximum of $41 \%$ for barley and $31 \%$ for potato of the total available water was depleted. Figure 1 shows pictures of the large and mini-lysimeter with and without vegetation, including the immediate area outside.
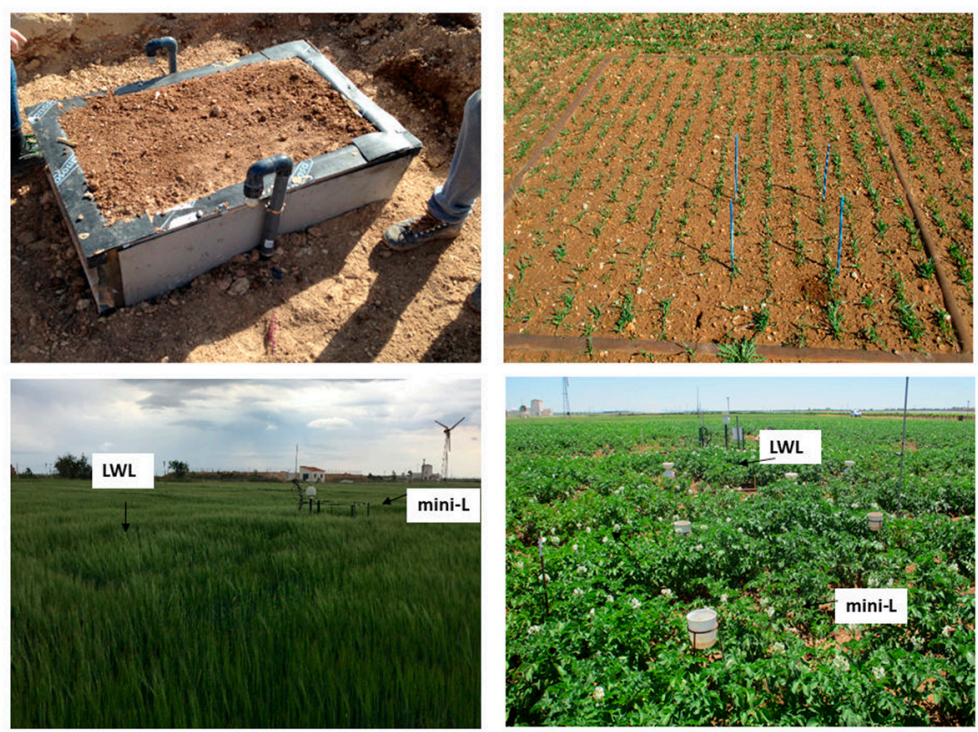

Figure 1. Detail of the mini-lysimeter (mini-L) installation before sowing the barley crop (top left); barley inside the large weighing lysimeter (LWL) on 15 March 2017 (top right); overview of the two lysimeters and the surrounding field with barley on 18 May 2017 (bottom left); overview of the lysimeter field and both lysimeters cultivated with potatoes on 15 May 2018 (bottom right).

Barley and potato $\mathrm{ET}_{\mathrm{C}}$ measurements were taken with both a well-established LWL and a removable mini-L. The lysimeters used in our study met all the requirements proposed by [9], aiming to ensure the representativeness of ET $_{\mathrm{C}}$ measurements, such as a minimum $50 \mathrm{~m}$ of fetch around the lysimeter, and the vegetation inside and close to the lysimeter area having to be identical in height, density, canopy cover and leaf area. In both lysimeters, daily mass change was used to determine $\mathrm{ET}_{\mathrm{C}}$ values. The lysimeter data were subjected to the quality control (QC) and quality assessment (QA) procedures recommended by [26].

The LWL is located in the centre of a 1-ha $(100 \times 100 \mathrm{~m})$ plot, with the container being $2.7 \mathrm{~m}$ long by $2.3 \mathrm{~m}$ wide by $1.7 \mathrm{~m}$ deep, resulting in a $6.21 \mathrm{~m}^{2}$ surface area and a total weight of around $14.5 \mathrm{Mg}$. The lysimeter soil-containing tank sits on a system of beams and counterbalances that offsets the dead weight of the soil and the tank and reduces the load on the beam by 1000:1. The lysimeter mass was determined using a data logger (CR10X, Campbell Scientific Ltd., Logan, UT, USA) that recorded the lysimeter steel load cell (model SB2, Epelsa Ind., Madrid, Spain) signal at $1 \mathrm{~s}$ frequency. Mass data were stored in 15-min, hourly and daily means. The lysimeter system has a mass resolution of $0.02 \mathrm{~mm}$, with an accuracy of $0.04 \mathrm{~mm}$ equivalent water depth. Detailed information about the technical features of this lysimeter facility is provided in [6]. Data collected during weight checks and calibration processes, rainfall events or any other task performed on the lysimeter container were not considered.

In 2017, before sowing the barley crop, a prototype of mini-L was installed less than $15 \mathrm{~m}$ away from the LWL (see Figure 1). In this device, three parts can be distinguished: (a) a reconstructed soil-containing tank, whose dimensions are $0.95 \mathrm{~m}$ long by $0.55 \mathrm{~m}$ wide by $0.30 \mathrm{~m}$ deep, resulting in $0.52 \mathrm{~m}^{2}$ surface area and a total weight of around $0.3 \mathrm{Mg}$, (b) a curved-bottom cylindrical steel tank to collect and measure drained water through the confined soil with a capacity of 41 and located under the cultivation tank, and (c) a weighing system to monitor water changes in the soil container and the drainage tank, consisting of 4 and 1 load cells for the soil and drainage container, respectively. 
The lysimeter mass and drainage water were determined using a data logger (CR300, Campbell Scientific Ltd., Logan, UT, USA) that recorded the mini-L and drainage steel load cells (Model 300, UTILCELL, S.A., Barcelona, Spain) signals at $1 \mathrm{~s}$ frequency. Mass and drainage data were stored in 1-min, 10-min, 30-min, hourly and daily means. The system allows for measurements of $\mathrm{ET}_{\mathrm{c}}$ and drainage with an accuracy of 0.03- and 0.002-mm water depth, respectively. At the end of the late season stage (between day 167 after sowing and harvest), this lysimeter did not work properly as the load cells malfunctioned and all lysimeter records were lost. Further information about the technical features of this prototype of lysimeter was recently reported by [14].

Furthermore, in 2018, aiming to monitor the $\mathrm{ET}_{\mathrm{C}}$ of a vegetable crop such as potato, the same mini-L prototype with identical technical characteristics [27], but with different dimensions $(1.5 \times 0.69 \times 0.5 \mathrm{~m})$, was installed close to the LWL (see Figure 1$)$. The cultivation tank containing the reconstructed soil has a surface area of $1.04 \mathrm{~m}^{2}$ and a total weight of around $0.9 \mathrm{Mg}$. In this case, the drainage tank has a capacity of $10 \mathrm{~L}$. The lysimeter and drainage tank mass measurement accuracy in water depth equivalent were 0.03 and $0.002 \mathrm{~mm}$, respectively.

\subsection{Agro-Meteorological Station, Reference Evapotranspiration and Crop Coefficients}

A standard automated weather station was used to monitor meteorological conditions during the two growing seasons. This station was installed at the lysimeter facility on a 1.5 ha reference grass surface and located about $100 \mathrm{~m}$ from the mini- and large lysimeter used in this study. All sensors were set up between heights of 1.5 and $2.0 \mathrm{~m}$. Measurements of short-wave and long-wave radiation, air temperature, relative humidity, precipitation, wind speed and direction were recorded in two CR-10X data loggers (Campbell Scientific, Inc., Logan, UT, USA) at different time steps, i.e., 15-min, hourly and daily. In addition, precipitation was measured by lysimeter mass change, which was tested using rain gauge data. Daily $\mathrm{ET}_{\mathrm{o}}$ was computed using the FAO56 Penamn-Monteith (FAO56 PM-ET $_{\text {) }}$ equation which has previously been tested in our lysimeter facility, showing satisfactory performance $[6,8]$.

Single $\mathrm{K}_{\mathrm{c}}$ values for barley and potato crops were calculated as the ratio of $\mathrm{ET}_{\mathrm{C}}$ measured in both lysimeters to $\mathrm{ET}_{\mathrm{o}}$ computed with the FAO56 PM-ET $\mathrm{O}$ equation (i.e., $\mathrm{K}_{\mathrm{C}}=\mathrm{ET}_{\mathrm{C}} / \mathrm{ET}_{\mathrm{O}}$ ). The dual $\mathrm{K}_{\mathrm{c}}$ was determined according to the FAO56 approach [24], recently updated by [2,3]. The basal crop coefficient $\left(\mathrm{K}_{\mathrm{cb}}\right)$, representing the crop transpiration, was estimated as the difference between single $\mathrm{K}_{\mathrm{c}}$ values (obtained from lysimeter measurements as referred to above) minus the soil evaporation coefficient $\left(\mathrm{K}_{\mathrm{e}}\right)$ estimated using the method described by [24]. The values of the main parameters used to compute $\mathrm{K}_{\mathrm{e}}$ were as follows: total evaporable water (TEW), $25 \mathrm{~mm}$, considering $0.10 \mathrm{~m}$ depth of the surface soil layer that is subject to drying by way of evaporation; readily evaporable water (REW), $10 \mathrm{~mm}$; fraction of soil surface wetted $\left(\mathrm{f}_{\mathrm{W}}\right)$ by sprinkler irrigation (1.0) and by precipitation (1.0). Additionally, $\mathrm{K}_{\mathrm{c} \text { max }}$, evaporation reduction coefficient $\left(\mathrm{K}_{\mathrm{r}}\right)$ and exposed and wetted soil fraction $\left(\mathrm{f}_{\mathrm{ew}}\right)$ were calculated using the equations proposed by [24]. $\mathrm{K}_{\mathrm{c}}$ and $\mathrm{K}_{\mathrm{cb}}$ values were adjusted to a segmented curve representing initial, crop development, mid-season and late season crop growth stages as a function of days after sowing. In addition, mid- and end-season single and basal crop coefficients (i.e., $\mathrm{K}_{\mathrm{c} \text { mid }}$ and $\mathrm{K}_{\mathrm{cb} \text { mid }}$, and $\mathrm{K}_{\mathrm{c} \text { end }}$ and $\mathrm{K}_{\mathrm{cb} \text { end }}$ ) values observed were adjusted to sub-humid climate with moderate wind speed measured at $2 \mathrm{~m}$ height $\left(\mathrm{u}_{2}\right)$ where $\mathrm{RH}_{\mathrm{min}}=45 \%$ and $\mathrm{u}_{2}=2 \mathrm{~m} \mathrm{~s}^{-1}$, as established in FAO56 [2,3,24].

\subsection{Ancillary Crop Parameters: Crop Phenology, Vegetation Fractional Cover and Crop Height}

During the two experimental seasons, barley (2017) and potato (2018) crop phenology was monitored weekly, following the BBCH scale for cereals [28] and potato [29], respectively. The fraction of ground surface covered by vegetation $\left(f_{c}\right)$ and crop height $(h)$ were determined every 5-10 days from crop emergence until harvest, aiming to monitor crop development during the 2017 and 2018 crop seasons. The estimation of $f_{c}$ was based on the methodology for calculating green canopy cover described by [30]. Digital pictures were periodically taken at solar noon and vertically from about 2-m height. This approach used a 
supervised classification technique with the maximum probability algorithm, assigning the current classes of green canopy in the image. The observed $f_{c}$ data (ground measurements) were adjusted to third-order polynomial functions for crop season.

\subsection{Mini-Lysimeter Performance Evaluation}

Mini-L performance in monitoring crop evapotranspiration was assessed using $\mathrm{ET}_{\mathrm{C}}$ observations from a well-established LWL. Both data sets of $\mathrm{ET}_{\mathrm{C}}$ were compared by using the lineal regression analysis (the intercept, slope, coefficient of determination $\left(\mathrm{R}^{2}\right)$ and significance of the linear model and their coefficients) and three types of difference measures, specifically, the root mean square error (RMSE), the mean bias error (MBE) and the index of agreement (d), as described by [31]. In addition, the normality, homoscedasticity (Shapiro-Wilk and Barlett test, respectively) and ANOVA tests were used to determine whether the $\mathrm{ET}_{\mathrm{c}}$ values measured by both systems showed differences. Finally, the linear relationships between the derived $\mathrm{K}_{\mathrm{cb}}$ and $\mathrm{f}_{\mathrm{c}}$ were also analysed. The statistical analysis was carried out with the [32].

\section{Results}

\subsection{Meteorological Conditions during the Barley and Potato Seasons}

In general, and excepting the accumulated rainfall, weather conditions during both cropping seasons were similar to the long-term average data (records registered during the last 30 years, 1987-2016) obtained from a weather station located at the experimental site. Thus, monthly average air temperature ranged between 7.4 and $25.5^{\circ} \mathrm{C}$, wind speed between 2.4 and $3.9 \mathrm{~m} \mathrm{~s}^{-1}$, net radiation between 3.6 and $16.5 \mathrm{MJ} \mathrm{m}^{-2} \mathrm{~d}^{-1}$ and $\mathrm{ET}_{\mathrm{o}}$ between 1.7-7.3 $\mathrm{mm} \mathrm{d}^{-1}$ (Figure 2). However, in both growing seasons, cumulative rainfall was around 30\% less than the long-term average, resulting in $104 \mathrm{~mm}$ and $111 \mathrm{~mm}$ for the barley and potato seasons, respectively. Rainfall events were concentrated during late winter and spring (Figure 2).
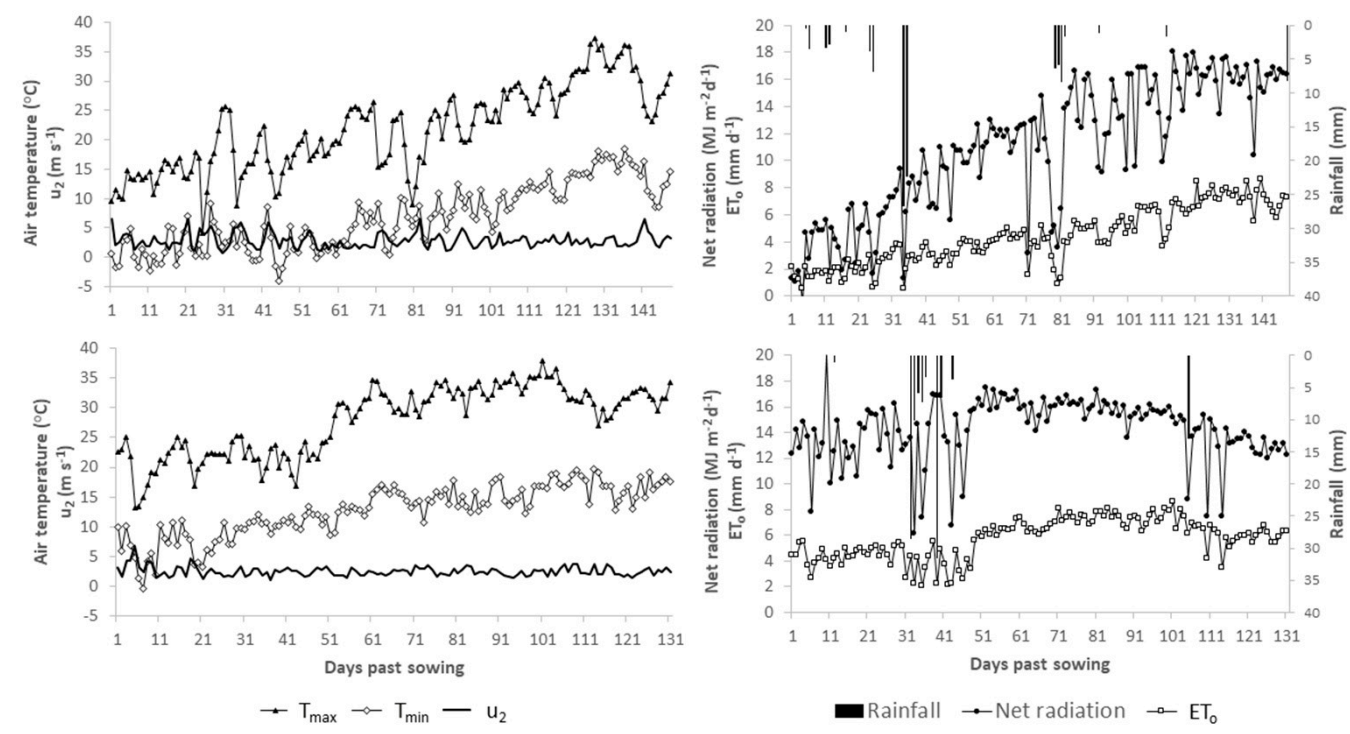

Figure 2. Daily values of maximum $\left(\mathrm{T}_{\max }\right)$ and minimum $\left(\mathrm{T}_{\min }\right)$ air temperature, wind speed $\left(u_{2}\right)$, net radiation, rainfall and reference evapotranspiration $\left(\mathrm{ET}_{\mathrm{o}}\right)$ for 2017 (top graphs) and 2018 (bottom graphs) seasons.

\subsection{Crop Development, Evapotranspiration Values, and Applied Irrigation Water}

Figure 3 shows the evolution of canopy cover across the barley (top graph) and potato (bottom graph) growing seasons. For both barley and potato crop, the evolution of $f_{c}$ was similar within the large and mini-lysimeter, with no significant differences between the two data sets (statistical analysis not shown). In the barley growing season, maximum $\mathrm{f}_{\mathrm{c}}$ 
values were reached between 90 and 125 days after sowing, ranging between 0.8 and 0.88 . The maximum crop height $(0.7 \mathrm{~m})$ was reached in mid-May (mid-season stage). In 2018, potato crop height reached $0.65 \mathrm{~m}$ about 65 days after sowing and the maximum canopy cover $(0.98)$ was reached in late June (60 days after planting).

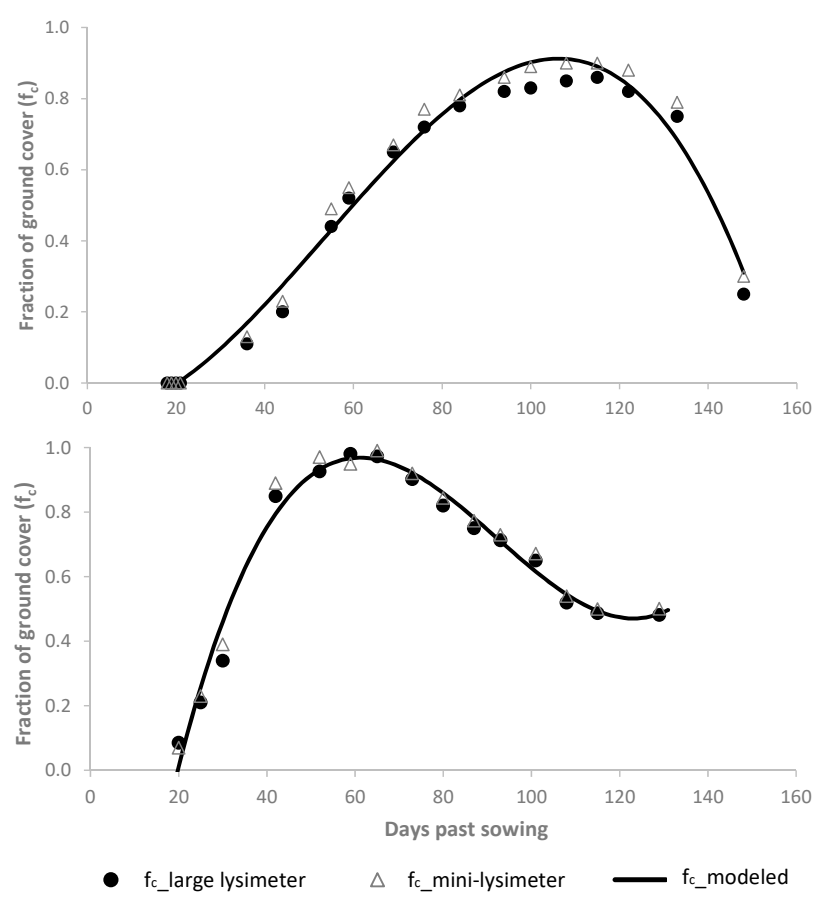

Figure 3. Evolution of the fraction of ground cover throughout the barley (top) and potato (bottom) growing seasons. Dots and triangles are ground measurements within the large and mini-lysimeter, respectively. In both seasons, a third-degree polynomial function was fitted to observations as follows: $\mathrm{y}=1.735 \times 10^{-6} \mathrm{x}^{3}+2.802 \times 10^{-4} \mathrm{x}^{2}-7.943 \times 10^{-4} \mathrm{x}-0.085 ; \mathrm{R}^{2}=0.984$ for barley in 2017 and $y=4.203 \times 10^{-6} x^{3}-1.162 \times 10^{-3} x^{2}+0.095 x-1.457 ; R^{2}=0.973$ for potato in 2018.

In 2017, the dates of critical growth stages were as follows: emergence (coleoptile penetrates soil surface, $\mathrm{BBCH}$ code of 09) on 1 March, beginning of tillering (start of crop development, $\mathrm{BBCH}$ code of 21) on 20 March, flag leaf fully unrolled (BBCH code of 39) on 25 April, soft dough (BBCH code of 85) on 9 June and fully ripe (BBCH code of 89 ) on 4 July. Regarding the potato crop, the dates of essential growth stages were the following: emergence on 10 May 6th leaf of main stem unfolded (BBCH code of 16) on 22 May, tuber initiation (BBCH code of 40 ) on 5 June, $70 \%$ of total final tuber mass reached (BBCH code of 47) on 14 July, and skin set complete (BBCH code of 49) on 2 September. Barley grain yield at 13\% moisture content (i.e., standard commercial yield) was $6781 \pm 359 \mathrm{~kg} \mathrm{ha}^{-1}$ within both lysimeters' surface effective area and the surrounding field, which is slightly higher than the average barley yield under irrigated conditions in Albacete province (SE Spain). In the 2018 season, the potato yield obtained in the mini- and large lysimeter surface areas, and the nearby field was similar $\left(35,483 \pm 4046 \mathrm{~kg} \mathrm{ha}^{-1}\right)$. This yield was also higher than the average yield of irrigated potatoes in the study site.

Figures 4 and 5 show the seasonal water supply from rainfall and irrigation (top graph) and the daily $\mathrm{ET}_{\mathrm{c}}$ and $\mathrm{FAO}-56 \mathrm{ET}_{\mathrm{o}}$ data (bottom graph) for each weighing lysimeter for the 2017 and 2018 seasons, respectively. In the barley season (Figure 4), the accumulated irrigation applied was $433.2 \mathrm{~mm}$ for the LWL and $455.7 \mathrm{~mm}$ for the mini-L, resulting in a total water supply (irrigation + rainfall) of $537.3 \mathrm{~mm}$ and $559.8 \mathrm{~mm}$, respectively. In both lysimeters, $\mathrm{ET}_{\mathcal{C}}$ values increased quickly during the crop development stage, favored by both a significant increase in the fraction of ground covered by vegetation and the evaporative demand. Peak $\mathrm{ET}_{\mathrm{c}}$ was reached during the mid-season stage, coinciding with maximum $\mathrm{f}_{\mathrm{c}}$ values, ranging 
between 0.8 and 0.88 , and declined during late season stage as the crop senescence progressed. Seasonal measured barley $\mathrm{ET}_{\mathrm{c}}$ was 471 and $462 \mathrm{~mm}$ in the LWL and mini-L, respectively.
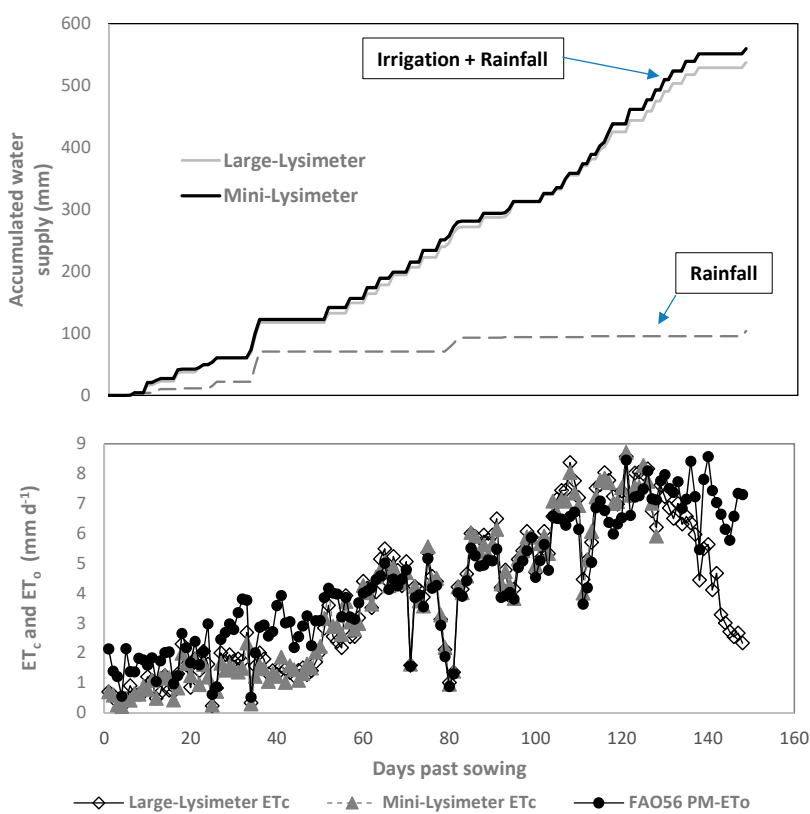

Figure 4. Seasonal rainfall and total water supply to each lysimeter for barley (top). Daily $\mathrm{ET}_{\mathrm{c}}$ values for barley from each weighing lysimeter and the computed grass FAO56 PM-ET from the daily weather data (bottom).

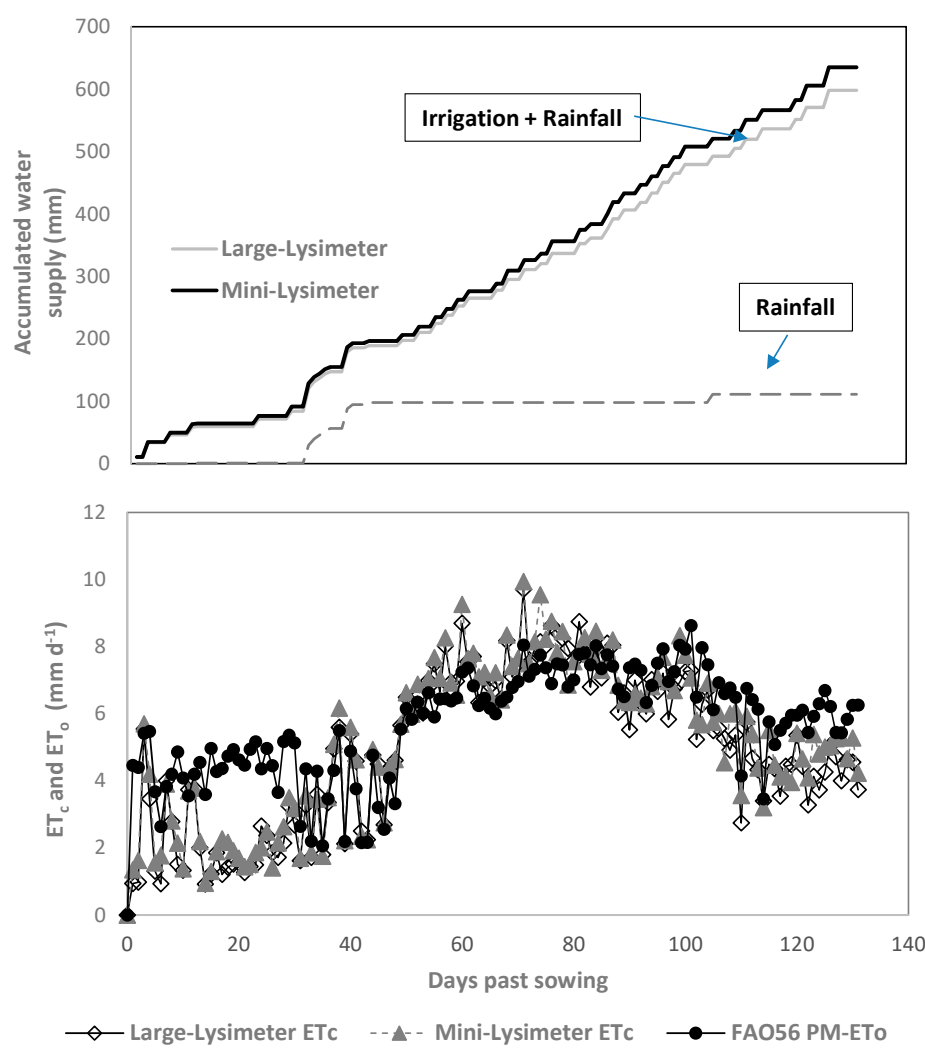

Figure 5. Seasonal rainfall and total water supply to each lysimeter for potato (top). Daily $\mathrm{ET}_{\mathrm{C}}$ values

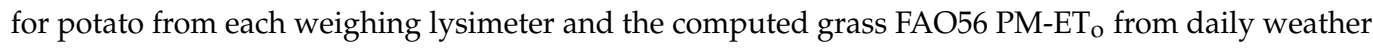
data (bottom). 
In 2018 (potato season, Figure 5), the seasonal supplied water was $597.7 \mathrm{~mm}$ and $634.7 \mathrm{~mm}$ for the large and mini-lysimeter, respectively. The total rainfall over the growing season was $111 \mathrm{~mm}$, with the total irrigation water applied being $487 \mathrm{~mm}$ for the LWL and $524 \mathrm{~mm}$ for the mini-L. The pattern of the potato $\mathrm{ET}_{\mathrm{c}}$ data during the crop cycle was similar to that of the barley, with maximum $\mathrm{ET}_{\mathrm{C}}$ values by mid-July (mid-season stage) declining during the late season as $\mathrm{f}_{\mathrm{C}}$ values dropped (Figure 5). Seasonal potato $\mathrm{ET}_{\mathrm{C}}$ measured in the large and mini-lysimeter was 649 and $679 \mathrm{~mm}$, respectively.

The grass FAO56 reference $\mathrm{ET}_{\mathrm{o}}$ during the barley season was $634 \mathrm{~mm}$ with maximum $\mathrm{ET}_{\mathrm{O}}$ occurring from mid-June to early July (harvest), coinciding with the late season stage. In 2018 (potato season), total $\mathrm{ET}_{\mathrm{o}}$ from planting to harvest was $749 \mathrm{~mm}$. Peak $\mathrm{ET}_{\mathrm{o}}$ was reached in the late mid-season stage, coinciding with mid-July $\left(>7 \mathrm{~mm} \mathrm{~d}^{-1}\right)$.

In accordance with the previously described irrigation management in the weighing lysimeters and the surrounding field, only the required amount of water used was replenished in the root zone. Therefore, no drainage was recorded from the tank of either weighing lysimeter during the 2-season study.

\subsection{Performance of a Small-Sized Weighing Lysimeter in Barley and Potato ET $T_{c}$ Measurements}

Figure 6 (top) shows the comparison of daily barley $\mathrm{ET}_{\mathrm{C}}$ monitored using a mini-L with measured $\mathrm{ET}_{\mathrm{C}}$ by means of a precision LWL. Both data sets kept to the normality and homoscedasticity assumptions. Thus, the linear model, as well as the slope of the linear regression line, whose value was 0.983 , showed high significance $(p<0.01)$, but not in the case of the intercept (Figure 6). In addition, the resulting errors in barley $\mathrm{ET}_{\mathrm{C}}$ estimation were an MBE of $-0.070 \mathrm{~mm} \mathrm{~d}^{-1}$ and an RMSE of $\pm 0.289 \mathrm{~mm} \mathrm{~d}^{-1}$. Finally, the underestimation of cumulative barley $\mathrm{ET}_{\mathrm{C}}$ was $2 \%$ during the growing season, while the index of agreement was 1.0, showing a perfect agreement between $\mathrm{ET}_{\mathrm{C}}$ values measured with both lysimeters. Figure 6 (bottom) presents the assessment of daily potato $\mathrm{ET}_{\mathrm{C}}$ measured with the mini-L vs. the LWL measurements. In this case, the linear model, the slope and the intercept were highly significant, and both data sets passed the normality and homoscedasticity assumptions. The slope of the linear regression line was 0.974 , and the resulting errors in daily potato $\mathrm{ET}_{\mathrm{C}}$ measurement using the mini-L were an MBE of $0.222 \mathrm{~mm} \mathrm{~d}^{-1}$ and an RMSE of $\pm 0.497 \mathrm{~mm} \mathrm{~d}^{-1}$. The overestimation of cumulative potato $\mathrm{ET}_{\mathrm{c}}$, from sowing to harvest, was $5 \%$. In this case, the index of agreement was 0.99. The goodness of fit indicators (i.e., slope/intercept, $\mathrm{R}^{2}$ and errors assessment) show a good agreement between the large and mini-lysimeter barley and potato $\mathrm{ET}_{\mathrm{C}}$ measurements at daily time step.

\subsection{Single and Dual Crop Coefficient Curves for Barley and Potato}

The results above show there are no significant differences between the $\mathrm{ET}_{\mathrm{C}}$ measurements from each weighing lysimeter. Therefore, the single and dual crop coefficient curves were adjusted to both data sets. Figure 7 presents the $\mathrm{K}_{\mathrm{c}}$ data for the barley (top graph) and potato (bottom graph) seasons, calculated as the ratio of $\mathrm{ET}_{\mathrm{c}}$ measurements from each lysimeter and $\mathrm{ET}_{\mathrm{O}}$ computed with the FAO56 $\mathrm{PM}-\mathrm{ET}_{\mathrm{O}}$ equation. These $\mathrm{K}_{\mathrm{c}}$ records were fitted to the typical FAO56 time-averaged $K_{c}$ curve, representing the changes in $\mathrm{K}_{\mathrm{C}}$ throughout the growing season. Four linear segments represent the four barley and potato growth stages, i.e., initial, crop development, mid-season and late season. The $\mathrm{K}_{\mathrm{c}}$ data during crop development and late season periods are linearly interpolated with time. The $\mathrm{K}_{\mathrm{c}}$ values for barley during initial $\left(\mathrm{K}_{\mathrm{c} \text { ini }}\right)$, mid-season $\left(\mathrm{K}_{\mathrm{c} \text { mid }}\right)$ and end-season $\left(\mathrm{K}_{\mathrm{c} \text { end }}\right)$ were $\mathrm{K}_{\mathrm{c} \text { ini }}: 0.55, \mathrm{~K}_{\mathrm{c} \text { mid }}: 1.11$ and $\mathrm{K}_{\mathrm{c} \text { end }}: 0.30$. These values for potato were $\mathrm{K}_{\mathrm{c} \text { ini }}: 0.50$, $\mathrm{K}_{\mathrm{c} \text { mid }}: 1.12$ and $\mathrm{K}_{\mathrm{c} \text { end }}: 0.65$. 


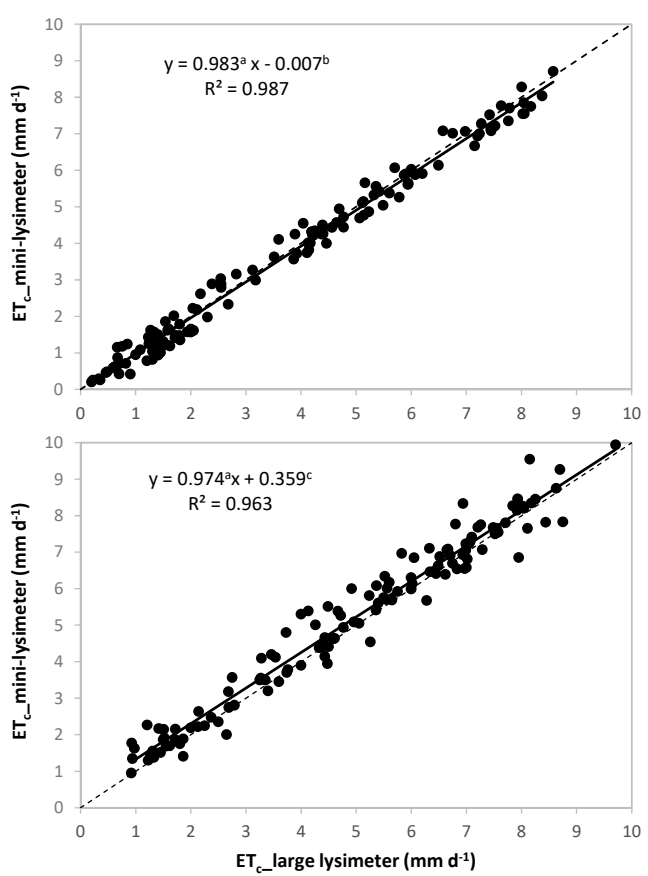

Figure 6. Large vs. mini-lysimeter $\mathrm{ET}_{\mathrm{C}}$ measurements at daily time step of barley (top) and potato (bottom). The number of records used for this evaluation was 128 and 131 for barley and potato, respectively. The line 1:1 is also plotted in the graphs (dashed line). a: the slope was highly significant different from $1(p<0.01){ }^{\mathrm{b}}$ : the intercept was not significantly different from $0(p>0.05)$. c: the intercept was highly significant different from $0(p<0.01)$.
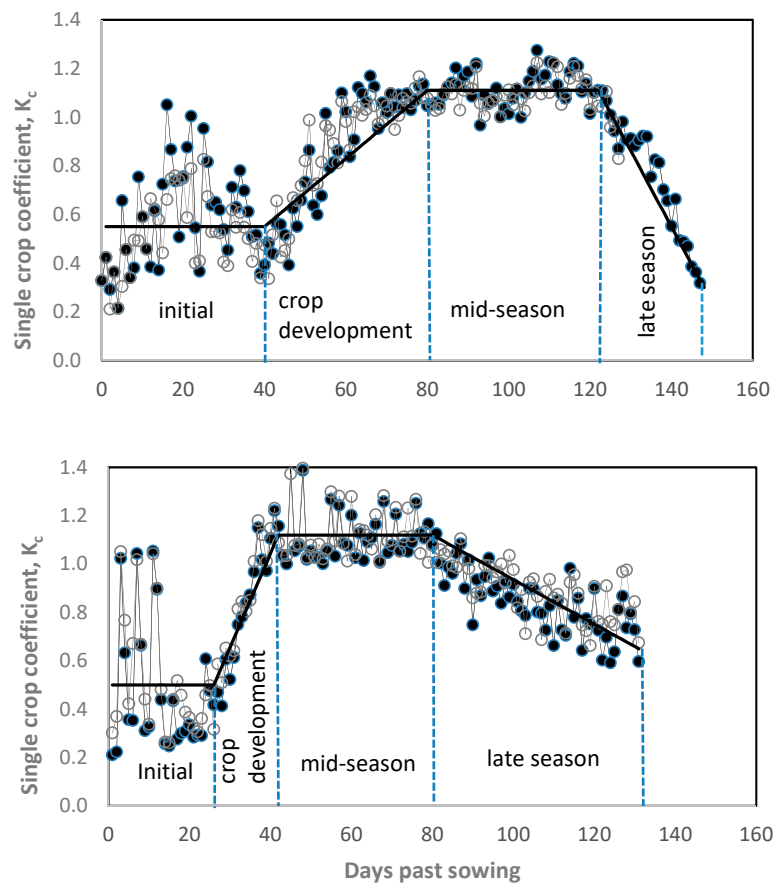

- $\mathrm{K}_{\mathrm{c}}$ large lysimeter $\bigcirc-\mathrm{K}_{\mathrm{c}}$ mini-lysimeter - Segmented curve $\left(\mathrm{K}_{\mathrm{cobs}}\right)$

Figure 7. Daily single crop coefficient $\left(\mathrm{K}_{\mathrm{c}}\right)$ data for barley (top graph) and potato (bottom graph) calculated as the ratio of $\mathrm{ET}_{\mathrm{C}}$ from each lysimeter and the grass $\mathrm{ET}_{\mathrm{O}}$ computed with the FAO56 $\mathrm{PM}-\mathrm{ET}_{\mathrm{O}}$ equation. The typical FAO56 segmented crop coefficient curve, with the identification of the four general growth stages, is adjusted $\left(\mathrm{K}_{\mathrm{cobs}}\right)$. 
In both crops, the pattern in the evolution of $K_{c}$ data was similar (Figure 7). During the initial growth phase (first stage), $\mathrm{K}_{\mathrm{c}}$ data $\left(\mathrm{K}_{\mathrm{c} \text { ini }}\right)$ showed a higher dispersion due to the effect of soil evaporation after a soil wetting event by rainfall and/or irrigation, when the $f_{c}$ values varied in a range of $0.0-0.1$ and $0.0-0.20$ for barley and potato, respectively. In crop development (second stage), the daily $\mathrm{K}_{\mathrm{c}}$ values rose as canopy cover increased until they reached maximum values at the beginning of mid-season stage. In the mid-season (third stage), $\mathrm{K}_{\mathrm{c}}$ values $\left(\mathrm{K}_{\mathrm{c} \text { mid }}\right)$ were the highest and more or less constant, when $\mathrm{f}_{\mathrm{c}}$ values varied in a range of $0.80-0.88$ and $0.87-0.98$ for barley and potato, respectively. In the fourth stage (late season), the daily $\mathrm{K}_{\mathrm{c}}$ values decreased as crop senescence occurred until it reached a minimum value at the end of this stage denominated $\mathrm{K}_{\mathrm{c} \text { end. }}$.

Figure 8 shows the partitioning of barley and potato $\mathrm{ET}_{\mathrm{C}}$ into canopy transpiration $\left(\mathrm{T}_{\mathrm{C}}\right)$, calculated by the basal crop coefficient $\left(\mathrm{K}_{\mathrm{cb}}\right)$, and soil evaporation $\left(\mathrm{E}_{\mathrm{s}}\right)$, estimated from the evaporation coefficient $\left(\mathrm{K}_{\mathrm{e}}\right)$, and conducted using the dual crop coefficient approach. The soil water evaporation is significant after a wetting event by rainfall or sprinkler irrigation application, mainly when $f_{c}$ values are low during the initial growth stage. In both crops, the pattern of the evolution of $\mathrm{K}_{\mathrm{e}}$ values was similar. These values were higher during the initial and the beginning of crop development stages, when the soil surface was wetted by irrigation and/or rainfall, and there was a significant amount of energy available for the soil water evaporation process. Moreover, $\mathrm{K}_{\mathrm{e}}$ values increased at the end of the late season stage as crop senescence progressed (i.e., $\mathrm{f}_{\mathrm{c}}$ values decrease). Furthermore, $\mathrm{K}_{\mathrm{cb}}$ values rapidly increased as vegetation cover expanded until the maximum values were reached during the mid-season stage. For the barley season, the $\mathrm{K}_{\mathrm{cb}}$ values in initial, mid- and end season stages were: $\mathrm{K}_{\mathrm{cb}}$ ini $0.10, \mathrm{~K}_{\mathrm{cb} \text { mid }}: 1.06$ and $\mathrm{K}_{\mathrm{cb} \text { end }}: 0.25$. The seasonal soil water evaporation totalled $112.5 \mathrm{~mm}$, corresponding to $20 \%$ of cumulative $\mathrm{ET}_{\mathrm{c}}$. Seasonal $\mathrm{T}_{\mathrm{c}}$ was calculated by multiplying $\mathrm{ET}_{\mathrm{o}}$ by average values of $\mathrm{K}_{\mathrm{cb} \text { obs }}$ (Figure 8, top graph), resulting in $455.5 \mathrm{~mm}$. In 2018 (potato season), $\mathrm{K}_{\mathrm{cb}}$ values were: $\mathrm{K}_{\mathrm{cb} \text { ini }}: 0.12, \mathrm{~K}_{\mathrm{cb} \text { midd }}: 1.08$ and $\mathrm{K}_{\mathrm{cb} \text { end }}$ : 0.45 . The seasonal $\mathrm{E}_{\mathrm{s}}$ component amounted to $108.5 \mathrm{~mm}$, equivalent to $16 \%$ of total $\mathrm{ET}_{\mathrm{c}}$. In the same way as for barley, the seasonal potato $\mathrm{T}_{\mathrm{c}}$ was estimated, resulting in $566.7 \mathrm{~mm}$. In both crops, $\mathrm{K}_{\mathrm{cb}}$ values during crop development and late season stages were linearly interpolated with time.
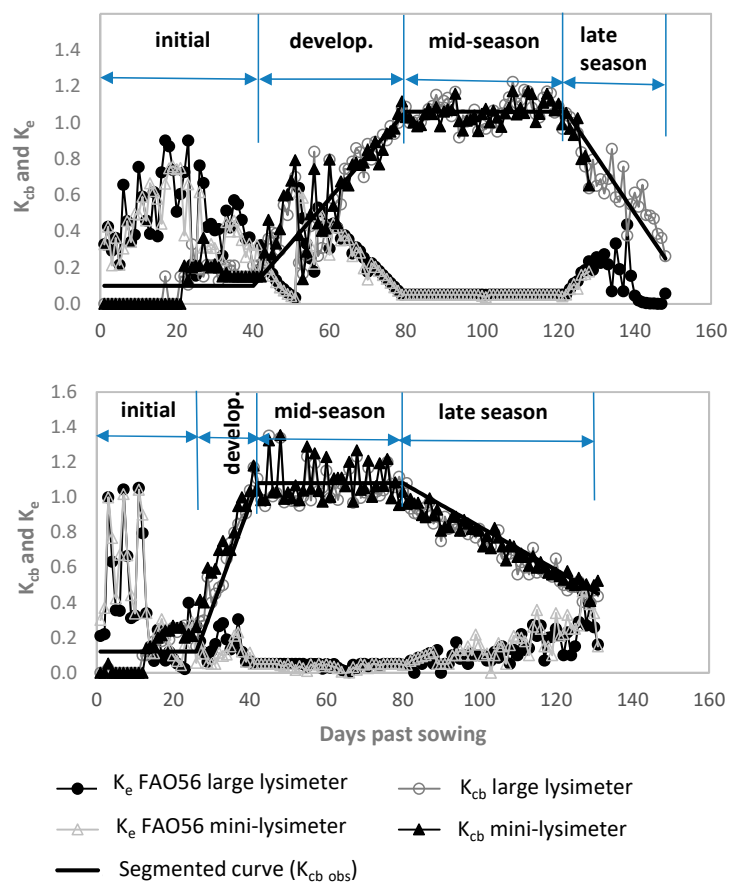

Figure 8. Dual crop coefficient for sprinkler-irrigated barley (top graph) and potato (bottom graph). $\mathrm{K}_{\mathrm{e}}$ values were estimated using the FAO56 approach and the basal crop coefficient, $\mathrm{K}_{\mathrm{cb}}$, was calculated from large and mini-lysimeter $\mathrm{K}_{\mathrm{c}}$ minus calculated $\mathrm{K}_{\mathrm{e}}$. The FAO56 segmented $\mathrm{K}_{\mathrm{cb}}$ curve was fitted with the identification of the four general crop growth stages. 
Table 1 shows an overview of the observed single and basal crop coefficients derived from measurements of both weighing lysimeters for mid- $\left(\mathrm{K}_{\mathrm{c} \mathrm{mid} \mathrm{(obs)}}\right.$ and $\left.\mathrm{K}_{\mathrm{cb} \text { mid (obs) }}\right)$ and end$\left(\mathrm{K}_{\mathrm{c} \text { end (obs) }}\right.$ and $\left.\mathrm{K}_{\mathrm{cb} \text { end (obs) }}\right)$ growth stages. In order to transfer the crop coefficient values to other areas with different weather conditions, these values were adjusted to standard sub-humid climate where $\mathrm{RH}_{\min }=45 \%$ and $\mathrm{u}_{2}=2 \mathrm{~m} \mathrm{~s}^{-1}$ (std, subindex), as defined in FAO56 [2,24]. The observed values of barley $\mathrm{K}_{\mathrm{c}}$ and $\mathrm{K}_{\mathrm{cb}}$ for end of season did not need adjusting to climate as they were lower than 0.45 . Furthermore, Table 1 shows ground measurements of ancillary crop parameters for the sprinkler-irrigated barley and potato, i.e., maximum root depth $\left(\mathrm{Z}_{\mathrm{r} \max }\right)$, maximum crop height $\left(\mathrm{h}_{\max }\right)$ and maximum canopy cover $\left(\mathrm{f}_{\mathrm{c} \max }\right)$.

Table 1. Single and basal crop coefficients derived from lysimeter measurements (observed, obs), and adjusted to standard climate $\left(\mathrm{RH}_{\min }=45 \%\right.$ and $\left.\mathrm{u}_{2}=2 \mathrm{~m} \mathrm{~s}^{-1}\right)$ (standard, std) for irrigated barley and potato.

\begin{tabular}{|c|c|c|c|c|c|c|c|}
\hline Crop & $\begin{array}{c}K_{\mathrm{c} \operatorname{mid}(\mathrm{obs})} \\
\left(\mathrm{K}_{\mathrm{c} \operatorname{mid}(\mathrm{std})}\right)\end{array}$ & $\begin{array}{l}K_{c \text { end }(o b s)} \\
\left(K_{c \text { end }(s t d)}\right)\end{array}$ & $\begin{array}{c}K_{\mathrm{cb} \text { mid (obs) }} \\
\left(\mathrm{K}_{\mathrm{cb} \text { mid (std) }}\right)\end{array}$ & $\begin{array}{l}K_{\mathrm{cb} \text { end }(\mathrm{obs})} \\
\left(\mathrm{K}_{\mathrm{cb} \text { end }(\mathrm{std})}\right)\end{array}$ & $* \mathrm{Z}_{\mathrm{r} \max }(\mathrm{m})$ & $\begin{array}{c}h_{\max } \\
(\mathrm{m})\end{array}$ & $f_{c \max }$ \\
\hline Barley & $1.11(1.05)$ & 0.30 (na) & $1.06(1.00)$ & 0.25 (na) & 0.40 & 0.70 & 0.88 \\
\hline Potato & $1.12(1.06)$ & $0.65(0.58)$ & $1.08(1.02)$ & $0.45(0.38)$ & 0.40 & 0.65 & 0.98 \\
\hline
\end{tabular}

*: limited by the soil depth; na: not applicable.

\subsection{Relationship between the Basal Crop Coefficient $\left(K_{c b}\right)$ and the Fraction of Ground Cover $\left(f_{c}\right)$}

In order to facilitate the extrapolation of the basal $\mathrm{K}_{\mathrm{c}}\left(\mathrm{K}_{\mathrm{cb}}\right)$ obtained for barley and potato to other areas, the relationship between the $\mathrm{K}_{\mathrm{cb}}$ values, from lysimeter measurements and evaporation estimates using the FAO56 approach, and the fraction of ground covered by the canopy were studied (Figure 9 ). In both crops, $K_{c b}$ was a linear function of $f_{c}$ with a coefficient of determination $\left(R^{2}\right)$ above 0.95 and the linear regression slopes were highly significant $(p<0.01)$ different from 1 .

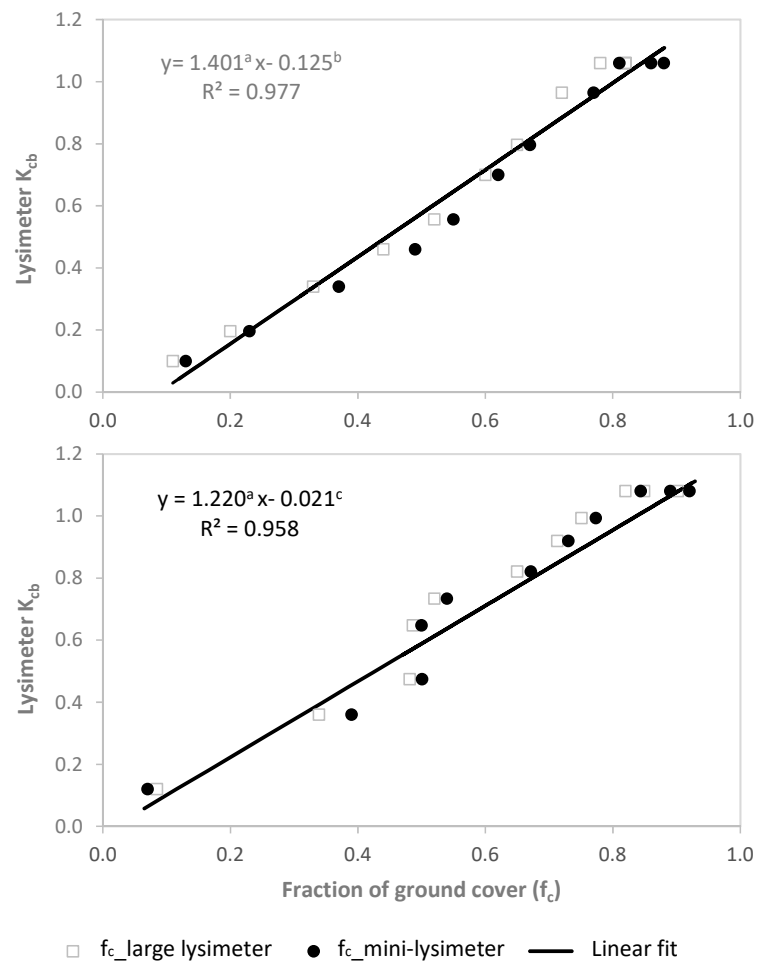

Figure 9. The relationship for barley (top) and potato (bottom) between the $\mathrm{K}_{\mathrm{cb}}$ obtained from weighing lysimeter measurements and the vegetation fractional cover $\left(\mathrm{f}_{\mathrm{c}}\right)$. ${ }^{\mathrm{a}}$ : the slope was highly significant different from $1(p<0.01){ }^{\mathrm{b}}$ : the intercept was significantly different from $0(p<0.05)$. c: the intercept was not significantly different from $0(p>0.05)$. 


\section{Discussion}

\subsection{Performance of a Small-Sized Weighing Lysimeter to Monitor Barley and Potato Evapotranspiration}

Weighing lysimeters are the standard systems to monitor $\mathrm{ET}_{\mathrm{C}}$ and derive new or updated crop coefficients [3,9]. However, in many cases, the lysimeter facilities are quite expensive, difficult to install and labour-intensive [33]. Therefore, the use of different prototypes of a small-sized or mini-L has expanded, with the aim of monitoring the soil water balance components, which seems an interesting alternative $[14,15]$. Firstly, these systems require correct calibration. The authors in [34] reported a calibration procedure for load cells used in mini-L aimed at improving the accuracy of $\mathrm{ET}_{\mathrm{c}}$ measurements, which is in accordance with the calibration procedure followed by the manufacturer of our mini-L in the laboratory. The authors in [26] reported that a quality assessment of any $\mathrm{ET}_{\mathrm{C}}$ measurement is essential to ensure data veracity, strongly recommending its comparison against independent measurements or models. Recently, Ref. [15] conducted a comparative study between an LWL (2-m diameter and 2.5-m deep) in operation since 1976 (long-established) and a monolithic mini-L (0.3-m diameter and 0.6-m deep) grown with grass. These authors reported a high level of agreement between measurements of soil water balance components (mainly ET and rainfall), despite important design differences. When only dry days were considered, the correlation between ET measurements from each lysimeter was high, with a $R^{2}$ of 0.97 and a small bias between them. In addition, their study reported different processing data approaches to improve the accuracy of lysimeter measurements. These novel results are in agreement with those obtained in our experiment. In a study conducted by [7], two monolithic LWL ( $9 \mathrm{~m}^{2}$ and $2.3 \mathrm{~m}$ deep) were used to measure sunflower $\mathrm{ET}_{\mathrm{c}}$ and produce updated crop coefficients. Although these authors did not carry out a comparison (i.e., regression analysis and error assessment) between $\mathrm{ET}_{\mathrm{c}}$ measurements from each lysimeter, a good agreement between them can be graphically observed. Furthermore, cumulative sunflower $\mathrm{ET}_{\mathrm{c}}$ measurements from each lysimeter varied in a range of $2-7 \%$ for the 2-year study, which agrees with that observed in our study, i.e., the mini-L underestimated by $2 \%$ and overestimated by $5 \%$ the seasonal $\mathrm{ET}_{\mathrm{C}}$ of barley and potato, respectively, compared with the LWL measurements.

To our knowledge, there is a lack of studies focused on comparing $\mathrm{ET}_{\mathrm{C}}$ measurements from two or more lysimeters. However, a large number of research studies have used precise weighing lysimeters to evaluate different measurement systems and estimation models of $\mathrm{ET}_{\mathrm{c}}$. For instance, Ref. [35] evaluated eddy covariance $(\mathrm{EC})$ cotton $\mathrm{ET}_{\mathrm{C}}$ measurements using an LWL located at Bushland, TX. These authors reported that $\mathrm{ET}_{\mathrm{C}}$ from the EC system significantly matched lysimeter measurements, with an MBE of $-0.03 \mathrm{~mm} \mathrm{~d}^{-1}$ and an RMSE of $\pm 0.5 \mathrm{~mm} \mathrm{~d}^{-1}$. In another study using data from a Bushland lysimeter facility, Ref. [36] assessed the one-step approach for estimating actual maize ET using different surface resistance models, with a bias (MBE) of $0.02 \mathrm{~mm}$ daytime $^{-1}$ and an RMSE of $\pm 0.57 \mathrm{~mm}^{\text {daytime }}{ }^{-1}$ for the best model, providing good estimations of actual maize ET. In research on our lysimeter facility, Ref. [21] assessed a simplified two-source energy balance (STSEB) model and an EC system to determine vineyard evapotranspiration using a monolithic large weighing lysimeter. These authors reported good agreement between adjusted EC measurements and lysimeter data, with an RMSE of $\pm 0.5 \mathrm{~mm} \mathrm{~d}^{-1}$, whereas, when the STSEB model was evaluated, an RMSE of $\pm 0.6 \mathrm{~mm} \mathrm{~d}^{-1}$ was obtained. These errors are similar to, or somewhat larger than, those obtained in our study. Thus, the prototype of mini-L used in our experiment is deemed capable of providing good measurements of $\mathrm{ET}_{\mathrm{C}}$.

\subsection{Evapotranspiration, Crop Coefficients and Ancillary Crop Parameters for Barley and Potato}

Recently, two review works conducted by [2,3] have updated the single and dual crop coefficients for vegetables and field crops reported by [24]. Regarding barley crop, in the last two decades a considerable number of scientific articles have been published reporting barley water use and producing new or updated crop coefficients. However, many of them lack the required information supporting the $\mathrm{ET}_{\mathrm{c}}$ measurements and the 
reported $\mathrm{K}_{\mathrm{c}}\left(\mathrm{K}_{\mathrm{cb}}\right)$ values. In addition, these reports (non-selected) did not use the grass FAO56 PM-ET ${ }_{\mathrm{O}}$ or ASCE-EWRI standardized PM-ET ${ }_{\mathrm{o}}$ equations [37], and the experiments were carried out under non-pristine cropping conditions. Thus, only three papers were selected, which were carried out under different environmental conditions and cropping systems. The study by [38] was conducted in northern Ethiopia, aiming to determine the barley water use and obtain its crop coefficients under surface irrigation system using a drainage lysimeter and the soil water balance (SWB) approach. Subsequently, Ref. [39] carried out an experiment in Domanínek (Czech Republic) using the Bowen ratio energy balance (BREB) method and the FAO56 dual $\mathrm{K}_{\mathrm{c}}$ approach with the aim of obtaining the barley ET and its partitioning into soil evaporation and crop transpiration. In a study conducted in Alpiarça (Portugal), Ref. [40] determined the single and dual crop coefficients of malt barley under sprinkler irrigation, using the SWB approach and SIMDualKc model. Derived from these studies, the range of observed $\mathrm{K}_{\mathrm{c}}$ values, after adjustment to temperate standard climate conditions, was 0.98-1.07 for mid-season $\left(\mathrm{K}_{\mathrm{c} \text { mid (std) }}\right)$ and $0.20-0.30$ for end-season $\left(\mathrm{K}_{\mathrm{c}}\right.$ end (std) $)$. Regarding the $\mathrm{K}_{\mathrm{cb}}$ values, $\mathrm{K}_{\mathrm{cb} \text { mid (std) }}$ ranged between 1.00-1.04 and $\mathrm{K}_{\mathrm{cb} \text { end (std) }}$ was 0.10. Based on these results, Ref. [2] reported updated FAO56 standard $\mathrm{K}_{\mathrm{c}}$ and $\mathrm{K}_{\mathrm{cb}}$ values for mid- and end-season as follows: $\mathrm{K}_{\mathrm{c} \text { mid (std) }}: 1.05, \mathrm{~K}_{\mathrm{c} \text { end (std) }}$ : 0.25 , $\mathrm{K}_{\mathrm{cb} \text { mid (std) }}: 1.00$ and $\mathrm{K}_{\mathrm{cb} \text { end (std) }}: 0.20$. Therefore, these $\mathrm{K}_{\mathrm{c}}$ and $\mathrm{K}_{\mathrm{cb}}$ values match our measurements. In addition, Ref. [2] updated indicative ancillary crop parameters, reporting $\mathrm{f}_{\mathrm{c} \max }$ varying in a range of $0.80-0.88$ and $\mathrm{h}_{\max }$ ranging between 0.7 and 0.9 , which is in agreement with our values.

Regarding the potato crop, Ref. [3] selected five robust studies conducted under different environmental conditions, agronomics, irrigation systems and crop management in Portugal, Tunisia, USA, Italy and Spain, reporting observed $\mathrm{K}_{\mathrm{c}}$ and/or $\mathrm{K}_{\mathrm{cb}}$ values [41-45]. $\mathrm{K}_{\mathrm{c} \text { mid (std) }}$ values observed and adjusted to temperate weather conditions were similar, ranging between 1.10 and 1.14 for long-season potato and 1.08 for short-season potato. However, $\mathrm{K}_{\mathrm{c} \text { end (std) }}$ values were somewhat different (range of 0.10-0.45); specifically, the low $\mathrm{K}_{\mathrm{c} \text { end (std) }}$ of 0.10 reported by [41]. This study refers to a specific management practice in which the crop is harvested after natural vine kill in the field. The study by [43] is the only one that differentiates between longand short-season potato. Our $\mathrm{K}_{\mathrm{c} \text { mid (std) }}$ is in agreement with that reported by [43]. Overall, our $\mathrm{K}_{\mathrm{c}}$ and $\mathrm{K}_{\mathrm{cb}}$ values derived from both lysimeters' measurements are somewhat lower than the values of updated standard $\mathrm{K}_{\mathrm{c}}\left(\mathrm{K}_{\mathrm{cb}}\right)$ reported by [3]. These slight differences can likely be explained by the lack of studies on short-season potato. Finally, updated standard crop parameters, such as $f_{c \max }$ and $h_{\max }$, reported by [3] matched our ground measurements.

In general, all these studies reported substantial differences in terms of seasonal barley and potato $\mathrm{ET}_{\mathrm{c}}$, due to different climate conditions, length of growing season, plant varieties, and the diversity of cropping systems for barley and potato in the different areas of the world where they are grown. Therefore, the levels of seasonal (cumulative) $\mathrm{ET}_{\mathrm{c}}$ reported in previous works and the present study are not comparable.

\subsection{Relationship between Basal Crop Coefficient and Canopy Cover for Barley and Potato}

Many studies have addressed the relationship between the single or basal crop coefficient and the fraction of ground cover or LAI for field and vegetable crops, vines and fruit trees [20,46-49]. However, to the best of our knowledge, this relationship has not been studied for barley and potato, although in a ground-breaking study conducted by [50] the actual ET and T of a potato crop measured in a lysimeter were closely related to LAI. The linear equation relating $\mathrm{K}_{\mathrm{cb}}$ and $\mathrm{f}_{\mathrm{c}}$ for barley and potato has previously been reported for other crops, such as wheat, sunflower and biomass sorghum [17,51,52], strawberries [53], wine grapes [54-56], and maize [49]. Ref. [19] related the evolution of young vineyard $\mathrm{K}_{\mathrm{c}}$ derived from lysimeter measurements over four seasons to the canopy cover, but no equation fittings were performed. Later, Ref. [20] found a robust linear relationship between $\mathrm{K}_{\mathrm{cb}}$, observed in a monolithic lysimeter, and $\mathrm{f}_{\mathrm{c}}$ for mature grapevines in a 3-year study. In other studies, non-linear (mainly, polynomial or exponential) relationship were found between $\mathrm{K}_{\mathrm{cb}}$ and $\mathrm{f}_{\mathrm{c}}$ for vegetable and row crops [48,57]. However, linear fits were observed during vegetation development, i.e., before mid-season, when crops reached maximum 
canopy cover. Finally, all these studies showed a good correlation between $\mathrm{K}_{\mathrm{cb}}$ and $\mathrm{f}_{\mathrm{c}}$ in agreement with our results, being a more robust approach to characterize the evolution of $\mathrm{K}_{\mathrm{cb}}$ throughout the growing season than that provided by the vegetation indices [58].

\section{Conclusions}

A large precision weighing lysimeter was used to assess a prototype of a small-sized removable weighing lysimeter to measure crop ET and to produce (derive) $\mathrm{K}_{\mathrm{c}}$ and $\mathrm{K}_{\mathrm{cb}}$ values for barley and potato crops. This comparison shows a good linear relationship between the $\mathrm{ET}_{\mathrm{C}}$ values observed with both lysimeters over a two-year period, resulting in reasonably small errors. Following the good agreement reached between both data sets, we obtained single $\left(\mathrm{K}_{\mathrm{c}}\right)$ and basal $\left(\mathrm{K}_{\mathrm{cb}}\right)$ crop coefficient values from weighing lysimeters' measurement and the grass FAO56 PM-ET $\mathrm{P}_{\mathrm{O}}$, which were adjusted to a four-stage standard segmented curve. $\mathrm{K}_{\mathrm{c}}$ and $\mathrm{K}_{\mathrm{cb}}$ values for mid- and end-season $\left(\mathrm{K}_{\mathrm{c}}\left(\mathrm{K}_{\mathrm{cb}}\right)_{\text {end }}\right.$ only for the case of potato) were adjusted to temperate sub-humid and calm conditions (i.e., $\mathrm{RH}_{\min }=45 \%$ and $\mathrm{u}_{2}=2 \mathrm{~m} \mathrm{~s}^{-1}$ ), making it possible to transfer them between climates and locations for irrigation management. The good agreement found between $\mathrm{f}_{\mathrm{c}}$ and $\mathrm{K}_{\mathrm{cb}}$ shows that it is an accurate and transferable methodology for estimating $\mathrm{K}_{\mathrm{cb}}$ for barley and potato. It can be concluded that this prototype of a mini-lysimeter is reliable to measure crop evapotranspiration and derive accurate crop coefficients when they are correctly managed, and the required efforts are made to keep the vegetation inside the lysimeter surface area under similar development conditions to those in the surrounding field. Thus, these measurement systems can help achieve sustainable irrigation water management and increase the water productivity of field and vegetable crops. Finally, it would be desirable when using removable mini-lysimeters to have two in the same field with the purpose of conducting the appropriate quality control/quality assessment procedures for $\mathrm{ET}_{\mathrm{C}}$ measurements.

Author Contributions: Conceptualization, J.M.T., A.D. and R.L.-U.; methodology, R.L.-U., L.S. and J.J.P.; software, R.L.-U., L.S. and Á.M.-R.; validation, R.L.-U., J.J.P. and F.M.; formal analysis, R.L.-U., J.J.P. and F.M.; investigation, R.L.-U., J.J.P., L.S. and F.M.; resources, J.M.T., A.D. and R.L.-U.; data curation, R.L.-U. and J.J.P.; writing-original draft preparation, R.L.-U.; writing-review and editing, R.L.-U., J.J.P., F.M., A.D. and Á.M.-R.; visualization, R.L.-U. and J.M.T.; supervision, R.L.-U., A.D. and J.M.T.; project administration, A.D. and J.M.T.; funding acquisition, A.D. and J.M.T. All authors have read and agreed to the published version of the manuscript.

Funding: This research was funded by "Agencia Estatal de Investigación, Spain" with FEDER co-financing Project AGL2017-82927-C3-3-R.

Institutional Review Board Statement: Not applicable.

Informed Consent Statement: Not applicable.

Data Availability Statement: The data presented in this study are available on request from the corresponding author.

Acknowledgments: R. López-Urrea acknowledges the support of the Sport, Culture and Education Council (JCCM, Spain), together with FEDER funds, throughout the "ANIATEL" project (SBPLY/17/180501/000357). Authors thank the support from the European Commission and PRIMA program with project "SUPROMED” (grant number: 1813).

Conflicts of Interest: The authors declare no conflict of interest.

\section{References}

1. López-Urrea, R.; Sánchez, J.M.; de la Cruz, F.; González-Piqueras, J.; Chávez, J.L. Evapotranspiration and Crop Coefficients from Lysimeter Measurements for Sprinkler-Irrigated Canola. Agric. Water Manag. 2020, 239. [CrossRef]

2. Pereira, L.S.; Paredes, P.; Hunsaker, D.J.; López-Urrea, R.; Mohammadi Shad, Z. Standard Single and Basal Crop Coefficients for Field Crops. Updates and Advances to the FAO56 Crop Water Requirements Method. Agric. Water Manag. 2021, 243. [CrossRef]

3. Pereira, L.S.; Paredes, P.; López-Urrea, R.; Hunsaker, D.J.; Mota, M.; Mohammadi Shad, Z. Standard Single and Basal Crop Coefficients for Vegetable Crops, an Update of FAO56 Crop Water Requirements Approach. Agric. Water Manag. $2021,243$. [CrossRef] 
4. Jensen, M.E.; Burman, R.D.; Allen, R.G. Evapotranspiration and Irrigation Water Requirements; American Society of Civil Engineers: Reston, VA, USA, 1990; Volume 70, p. 332.

5. Berengena, J.; Gavilán, P. Reference Evapotranspiration Estimation in a Highly Advective Semiarid Environment. J. Irrig. Drain Eng. 2005, 131, 147-163. [CrossRef]

6. López-Urrea, R.; Martín de Santa Olalla, F.; Fabeiro, C.; Moratalla, A. Testing Evapotranspiration Equations Using Lysimeter Observations in a Semiarid Climate. Agric. Water Manag. 2006, 85, 15-26. [CrossRef]

7. Howell, T.A.; Evett, S.R.; Tolk, J.A.; Copeland, K.S.; Marek, T.H. Evapotranspiration, Water Productivity and Crop Coefficients for Irrigated Sunflower in the U.S. Southern High Plains. Agric. Water Manag. 2015, 162, 33-46. [CrossRef]

8. Trigo, I.F.; de Bruin, H.; Beyrich, F.; Bosveld, F.C.; Gavilán, P.; Groh, J.; López-Urrea, R. Validation of Reference Evapotranspiration from Meteosat Second Generation (MSG) Observations. Agric. For. Meteorol. 2018, 259, 271-285. [CrossRef]

9. Allen, R.G.; Pereira, L.S.; Howell, T.A.; Jensen, M.E. Evapotranspiration Information Reporting: I. Factors Governing Measurement Accuracy. Agric. Water Manag. 2011, 98, 899-920. [CrossRef]

10. Evett, S.R.; Schwartz, R.C.; Howell, T.A.; Louis Baumhardt, R.; Copeland, K.S. Can Weighing Lysimeter ET Represent Surrounding Field ET Well Enough to Test Flux Station Measurements of Daily and Sub-Daily ET? Adv. Water Resour. 2012, 50, 79-90. [CrossRef]

11. Howell, T.A. LYSIMETRY. In Encyclopedia of Soils in the Environment; Elsevier Ltd.: Amsterdam, The Netherlands, 2005; pp. 379-386.

12. Payero, J.O.; Irmak, S. Construction, Installation, and Performance of Two Repacked Weighing Lysimeters. Irrig. Sci. 2008, 26, 191-202. [CrossRef]

13. Ruiz-Peñalver, L.; Vera-Repullo, J.A.; Jiménez-Buendía, M.; Guzmán, I.; Molina-Martínez, J.M. Development of an Innovative Low Cost Weighing Lysimeter for Potted Plants: Application in Lysimetric Stations. Agric. Water Manag. 2015, 151, 103-113. [CrossRef]

14. Nicolás-Cuevas, J.A.; Parras-Burgos, D.; Soler-Méndez, M.; Ruiz-Canales, A.; Molina-Martínez, J.M. Removable Weighing Lysimeter for Use in Horticultural Crops. Appl. Sci. 2020, 10, 4865. [CrossRef]

15. Ruth, C.E.; Michel, D.; Hirschi, M.; Seneviratne, S.I. Comparative Study of a Long-Established Large Weighing Lysimeter and a State-of-the-Art Mini-Lysimeter. Vadose Zone J. 2018, 17, 170026. [CrossRef]

16. Martí, P.; González-Altozano, P.; López-Urrea, R.; Mancha, L.A.; Shiri, J. Modeling Reference Evapotranspiration with Calculated Targets. Assessment and Implications. Agric. Water Manag. 2015, 149, 81-90. [CrossRef]

17. López-Urrea, R.; Martínez-Molina, L.; de la Cruz, F.; Montoro, A.; González-Piqueras, J.; Odi-Lara, M.; Sánchez, J.M. Evapotranspiration and Crop Coefficients of Irrigated Biomass Sorghum for Energy Production. Irrig. Sci. 2016, 34, 287-296. [CrossRef]

18. López-Urrea, R.; Montoro, A.; López-Fuster, P.; Fereres, E. Evapotranspiration and Responses to Irrigation of Broccoli. Agric. Water Manag. 2009, 96, 1155-1161. [CrossRef]

19. Montoro, A.; Urrea, R.L.; Mañas, F.; Fuster, P.L.; Fereres, E. Evapotranspiration of Grapevines Measured by a Weighing Lysimeter in La Mancha, Spain; International Society for Horticultural Science: Leuven, Belgium, 2008; Volume 792, pp. 459-466.

20. López-Urrea, R.; Montoro, A.; Mañas, F.; López-Fuster, P.; Fereres, E. Evapotranspiration and Crop Coefficients from Lysimeter Measurements of Mature “Tempranillo" Wine Grapes. Agric. Water Manag. 2012, 112, 13-20. [CrossRef]

21. Sánchez, J.M.; López-Urrea, R.; Valentín, F.; Caselles, V.; Galve, J.M. Lysimeter Assessment of the Simplified Two-Source Energy Balance Model and Eddy Covariance System to Estimate Vineyard Evapotranspiration. Agric. For. Meteorol. 2019, 274, 172-183. [CrossRef]

22. Sánchez, J.M.; López-Urrea, R.; Doña, C.; Caselles, V.; González-Piqueras, J.; Niclòs, R. Modeling Evapotranspiration in a Spring Wheat from Thermal Radiometry: Crop Coefficients and E/T Partitioning. Irrig. Sci. 2015, 33, 399-410. [CrossRef]

23. Soldevilla-Martinez, M.; Quemada, M.; López-Urrea, R.; Muñoz-Carpena, R.; Lizaso, J.I. Soil Water Balance: Comparing Two Simulation Models of Different Levels of Complexity with Lysimeter Observations. Agric. Water Manag. 2014, 139, 53-63. [CrossRef]

24. Allen, R.; Pereira, L.; Raes, D.; Smith, M. Crop Evapotranspiration-Guidelines for Computing Crop Water Requirements; FAO Irrigation and Drainage Paper 56; FAO: Rome, Italy, 1998; p. 300.

25. Natural Resources Conservation Service Soil Survey Staff. Soil Taxonomy; United States Department of Agriculture Keys: Washington, DC, USA, 2014.

26. Allen, R.G.; Pereira, L.S.; Howell, T.A.; Jensen, M.E. Evapotranspiration Information Reporting: II. Recommended Documentation. Agric. Water Manag. 2011, 98, 921-929. [CrossRef]

27. Soler-Méndez, M.; Parras-Burgos, D.; Mas-Espinosa, E.; Ruíz-Canales, A.; Intrigliolo, D.S.; Molina-Martínez, J.M. Standardization of the Dimensions of a Portable Weighing Lysimeter Designed to Be Applied to Vegetable Crops in Mediterranean Climates. Sustainability 2021, 13, 2210. [CrossRef]

28. Lancashire, P.D.; Bleiholder, H.; Van Den Boom, T.; Langeluddeke, P.; Stausss, R.; Weber, E.; Witzenberger, A. A Uniform Decimal Code for Growth Stages of Crops and Weeds. Ann. Appl. Biol. 1991, 119, 561-601. [CrossRef]

29. Hack, H.; Gall, H.; Klemcke, T.; Klose, R.; Meier, U.; Strauss, R.; Witzen-berger, A. Phänologische Entwicklungsstadien Der Kartoffel (Solanum Tuberosum L.). Codierung Und Beschreibung Nach Der Erweiterten BBCH-Skala Mit Abbildungen. Nachrichtenbl. Deut. Pflanzenschutzd 1993, 45, 11-19. 
30. Cihlar, J.; Dobson, M.C.; Schmugge, T.; Hoogeboom, P.; Janse, A.R.P.; Baret, F.; Guyot, G.; Le Toan, T.; Pampaloni, P. Review Article Procedures for the Description of Agricultural Crops and Soils in Optical and Microwave Remote Sensing Studies. Int. J. Remote Sens. 1987, 8, 427-439. [CrossRef]

31. Willmott, C.J. Some Comments on the Evaluation of Model Performance. Bull. Am. Meteorol. Soc. 1982, 63, 1309-1313. [CrossRef]

32. R Core Team, R. A Language and Environment for Statistical Computing; R Core Team: Vienna, Austria, 2019.

33. Pütz, T.; Fank, J.; Flury, M. Lysimeters in Vadose Zone Research. Vadose Zone J. 2018, 17, 180035. [CrossRef]

34. Misra, R.K.; Padhi, J.; Payero, J.O. A Calibration Procedure for Load Cells to Improve Accuracy of Mini-Lysimeters in Monitoring Evapotranspiration. J. Hydrol. 2011, 406, 113-118. [CrossRef]

35. Chávez, J.L.; Howell, T.A.; Copeland, K.S. Evaluating Eddy Covariance Cotton ET Measurements in an Advective Environment with Large Weighing Lysimeters. Irrig. Sci. 2009, 28, 35-50. [CrossRef]

36. López-Urrea, R.; Chávez, J.L. One-Step Approach for Estimating Maize Actual Water Use: Part II. Lysimeter Evaluation of Variable Surface Resistance Models. Irrig. Sci. 2019, 37, 139-150. [CrossRef]

37. Allen, R.G.; Walter, I.A.; Elliott, R.L.; Howell, T.A.; Itenfisu, D.; Jensen, M.E.; Snyder, R.L. The ASCE Standardized Reference Evapotranspiration Equation; American Society of Civil Engineers: Reston, VA, USA, 2005.

38. Araya, A.; Habtu, S.; Haile, M.; Sisay, F.; Dejenie, T. Determination of Local Barley (Hordeum Vulgare) Crop Coefficient and Comparative Assessment of Water Productivity for Crops Grown Under the Present Pond Water in Tigray, Northern Ethiopia. Momona Ethiop. J. Sci. 2011, 3, 65-79. [CrossRef]

39. Pozníková, G.; Fischer, M.; Pohanková, E.; Trnka, M. Analyses of Spring Barley Evapotranspiration Rates Based on Gradient Measurements and Dual Crop Coefficient Model. Acta Univ. Agric. Et Silvic. Mendel. Brun. 2014, 62, 1079-1086. [CrossRef]

40. Pereira, L.S.; Paredes, P.; Rodrigues, G.C.; Neves, M. Modeling Malt Barley Water Use and Evapotranspiration Partitioning in Two Contrasting Rainfall Years. Assessing AquaCrop and SIMDualKc Models. Agric. Water Manag. 2015, 159, 239-254. [CrossRef]

41. Sousa, V.; Pereira, L.S. Regional Analysis of Irrigation Water Requirements Using Kriging Application to Potato Crop (Solanum Tuberosum L.) at TraÂs-Os-Montes. Agric. Water Manag. 1999, 40, 221-233. [CrossRef]

42. Zairi, A.; El Amami, H.; Slatni, A.; Pereira, L.S.; Rodrigues, P.N.; Machado, T. Coping with Drought: Deficit Irrigation Strategies for Cereals and Field Horticultural Crops in Central Tunisia. In Tools for Drought Mitigation in Mediterranean Regions; Rossi, G., Cancelliere, A., Pereira, L.S., Oweis, T., Shatanawi, M., Zairi, A., Eds.; Springer: Dordrecht, The Netherlands, 2003 ; pp. 181-201. ISBN 978-94-010-0129-8.

43. Tasumi, M.; Allen, R.G. Satellite-Based ET Mapping to Assess Variation in ET with Timing of Crop Development. Agric. Water Manag. 2007, 88, 54-62. [CrossRef]

44. Paredes, P.; D'Agostino, D.; Assif, M.; Todorovic, M.; Pereira, L.S. Assessing Potato Transpiration, Yield and Water Productivity under Various Water Regimes and Planting Dates Using the FAO Dual Kc Approach. Agric. Water Manag. 2018, 195, 11-24. [CrossRef]

45. Martínez-Romero, A.; Domínguez, A.; Landeras, G. Regulated Deficit Irrigation Strategies for Different Potato Cultivars under Continental Mediterranean-Atlantic Conditions. Agric. Water Manag. 2019, 216, 164-176. [CrossRef]

46. Villalobos, F.J.; Fereres, E. Evaporation Measurements beneath Corn, Cotton, and Sunflower Canopies. Agron. J. 1990, 82, 1153-1159. [CrossRef]

47. Goodwin, I.; Whitfield, D.M.; Connor, D.J. Effects of Tree Size on Water Use of Peach (Prunus Persica L. Batsch). Irrig. Sci. 2006, 24, 59-68. [CrossRef]

48. Bryla, D.R.; Trout, T.J.; Ayars, J.E. Weighing Lysimeters for Developing Crop Coefficients and Efficient Irrigation Practices for Vegetable Crops. HortScience 2010, 45, 1597-1604. [CrossRef]

49. Trout, T.J.; DeJonge, K.C. Crop Water Use and Crop Coefficients of Maize in the Great Plains. J. Irrig. Drain. Eng. 2018, 144, 04018009. [CrossRef]

50. Tanner, C.B.; Jury, W.A. Estimating Evaporation and Transpiration from a Row Crop during Incomplete Cover 1. Agron. J. 1976, 68, 239-243. [CrossRef]

51. López-Urrea, R.; Montoro, A.; Trout, T.J. Consumptive Water Use and Crop Coefficients of Irrigated Sunflower. Irrig. Sci. 2014, 32, 99-109. [CrossRef]

52. López-Urrea, R.; Montoro, A.; González-Piqueras, J.; López-Fuster, P.; Fereres, E. Water Use of Spring Wheat to Raise Water Productivity. Agric. Water Manag. 2009, 96, 1305-1310. [CrossRef]

53. Lozano, D.; Ruiz, N.; Gavilán, P. Consumptive Water Use and Irrigation Performance of Strawberries. Agric. Water Manag. 2016, 169, 44-51. [CrossRef]

54. Picón-Toro, J.; González-Dugo, V.; Uriarte, D.; Mancha, L.A.; Testi, L. Effects of Canopy Size and Water Stress over the Crop Coefficient of a "Tempranillo" Vineyard in South-Western Spain. Irrig. Sci. 2012, 30, 419-432. [CrossRef]

55. Ferreira, M.I.; Silvestre, J.; Conceição, N.; Malheiro, A.C. Crop and Stress Coefficients in Rainfed and Deficit Irrigation Vineyards Using Sap Flow Techniques. Irrig. Sci. 2012, 30, 433-447. [CrossRef]

56. Montoro, A.; Mañas, F.; López-Urrea, R. Transpiration and Evaporation of Grapevine, Two Components Related to Irrigation Strategy. Agric. Water Manag. 2016, 177, 193-200. [CrossRef]

57. Grattan, S.R.; Bowers, W.; Dong, A.; Snyder, R.L.; Carroll, J.J.; George, W. New Crop Coefficients Estimate Water Use of Vegetables, Row Crops. Calif. Agric. 1998, 52, 16-21. [CrossRef]

58. Johnson, L.F.; Trout, T.J. Satellite NDVI Assisted Monitoring of Vegetable Crop Evapotranspiration in California's San Joaquin Valley. Remote Sens. 2012, 4, 439-455. [CrossRef] 